\title{
O ciclo de vida de um meme: Delineamentos para o espalhamento a partir do ciberacontecimento em torno do caso da capivara-cachorro
}

\author{
Maria Clara Aquino Bittencourt ${ }^{1}$ \\ Christian Gonzatti
}

\begin{abstract}
Resumo: $O$ artigo analisa as dinâmicas das redes sociais como geradoras de cibersocialidades de ciberacontecimentos.A partir de uma publicação no site Facebook, que foi forjada por um ator social a fim de desenvolver compartilhamentos, buscamos destacar as diferenças entre viralização e espalhamento e os delineamentos que podem impulsionar a visibilidade em torno de determinado conteúdo. Desenvolvemos uma pesquisa exploratória para a aplicação da técnica de análise denominada como construção de sentidos em redes digitais, com os dados coletados. Por fim, pensamos no conceito de meme, proposto por Dawkins (1979), articulado aos conceitos explorados no artigo. Assim, constatamos que o caso da capivaracachorro sinaliza transformações culturais na sociedade, decorrentes das dinâmicas das cibersocialidades em torno dos ciberacontecimentos.
\end{abstract}

Palavras-chave:ciberacontecimento; meme; espalhamento; capivara-cachorro; redes sociais.

\begin{abstract}
This paper analyzes social networks dynamics as creators of cybersocialities, and therefore, of cyberevents. From a publication on Facebook, which was forged by a social actor in order to get shares, we sought to highlight the differences between viralization and spreading, and the designs that can boost the visibility around certain content. We developed an exploratory research to apply an analysis technique called construction of meaning in digital networks, with the collected data. Finally, we discuss the concept of meme, proposed by Dawkins (1979), as articulating with concepts explored in this article. Thus, we have found that the case of the "capybara-dog" signals to cultural changes in society, arising from the dynamics of the cybersocialities around cyberevents.
\end{abstract}

Keywords:cyberevent; meme; spreading; capibara-dog; social network.

1 Prof. Dra . do Programa de Pós-Graduação em Ciências da Comunicação da Universidade do Vale do Rio dos Sinos. E-mail: aquino.mariaclara@gmail.com.

2 Mestrando do Programa de Pós-Graduação em Ciências da Comunicação da Universidade do Vale do Rio dos Sinos. E-mail: christiangonzatti@gmail.com. 


\section{Introdução}

Este texto faz parte de uma pesquisa sobre ciberacontecimento que investiga a produção de sentido em redes digitais. As considerações aqui expostas partem de uma atividade exploratória realizada através de um método de análise ainda em desenvolvimento, que será melhor explicado ao longo do artigo, em torno de uma publicação 3 no Facebook que trouxe imagens de uma capivara como se, na verdade, fosse uma espécie rara de cachorro. A partir desta instância, surgiram diversos sentidos em torno do caso que, vistos a partir de uma perspectiva semiótica (HENN, 2014), traz considerações de grande relevância para questões mercadológicas e para o estudo dos memes (DAWKINS, 1979), a partir do espalhamento (JENKINS et al., 2013).

A primeira parte do artigo aborda o contextoda cibercultura (LEMOS, 2013) e dos sites de redes sociais (RECUERO, 2009) para explicar o campo e as práticas que propiciaram o espalhamento do objeto analisado, abrindo espaço para o estudo dos ciberacontecimentos (HENN, 2014), entendidos a partir da inspiração em conceitos semióticos, como a semiosfera (LOTMAN, 1996). Assim, as características da conversação em rede (RECUERO, 2014) possibilitam pensar nas especificidades em torno do ciberacontecimento da capivara-cachorro e explicar a convergência (JENKINS, 2006) e os delineamentos para o espalhamento (JENKINS et al., 2013), que levaram ao desenvolvimento da visibilidade em torno do caso e a consequente emergência de pauta jornalística. A quarte parte do artigo analisa os sentidos inaugurados em torno do casoda capivara-cachorro, trazendo considerações sobre a dimensão acontecimental que assumem algumas celebridades (SIMÕES, 2014). $\mathrm{O}$ último item analisa o ciclo de vida de um meme, abrangendo todas as considerações trazidas ao longo do artigo. Por último, entendemos a importância da pesquisa para constatações mercadológicas e culturais, sendo o ciberacontecimento um integrante destes campos.

\footnotetext{
3 Publicação em torno da qual a pesquisa se desdobra, feita no dia 19 de setembro de 2015 e movimentando uma série de sentidos a partir de comentários, curtidas e compartilhamentos. Disponível em: $<$ https://www.facebook.com/guiimatheus/posts/913133955436295?pnref=story\& m ref=message $>$. Acesso em: 16 fev. 2017.
} 


\section{Articulações entre a cibercultura e as redes sociais}

A cibercultura pode ser entendida como a sinergia entre a vida social e os diversos dispositivos eletrônicos que projetam redes telemáticas. Nela, a linguagem ganha novos contornos e o ser humano passa a agir com mais velocidade e potência, impulsionando a cibersociabilidade (LEMOS, 2013). Assim, a diversão, a teatralidade e o espetáculo ganham potência através do ciberespaço, principalmente por causa do tribalismo que vai acompanhar os grupos que se constroem neste campo de bits. "O tribalismo refere-se à vontade de estar junto (étre-ensemble), em que o que importa é o compartilhamento de emoções em comum" (LEMOS, 2013, p. 87). As redes sociais, então, funcionam como espaço em que se metabolizam as características da cibercultura.

Redes sociais fazem parte da sociabilidade desde os primórdios daquilo que se entende por humanidade. Por exemplo, quando se pensa em seres humanos ao redor de fogueiras, compartilhando histórias, pode-se, também, pensar em uma rede social. Recuero (2009), a partir de diversos autores que estudam redes e conexões, coloca que uma rede social é definida pelo conjunto de dois elementos: atores e suas conexões. Os atores podem ser instituições, grupos, pessoas, e é partir deles que se formam nós. As conexões são as interações e os laços sociais que esses atores mantém entre si. A rede, então, pode ser vista como uma metáfora para observar as especificidades da conexão de determinado grupo social. A cibercultura terá um papel determinante ao potencializar algumas características das redes sociais.

A partir dos rastros narrativos construídos por um ator social, que se liga consequentemente a outros atores sociais, podem eclodir novas formas de desenvolver visibilidade (RECUERO, 2009) em torno de determinado objeto que difere das práticas que eram associadas, antes, a apenas a mídia de massa. A visibilidade impera a partir de diversos valores de capitais, dentre eles, o relacional, que vai surgir a partir de valor que os laços entre atores desenvolvem em uma rede. Existem os laços fracos, que são as conexões que se instauram entre pessoas mais distantes, e os laços fortes, que são as conexões mais próximas. É a partir dos laços fracos que os conteúdos desenvolvem, em consequência, maior visibilidade. A interação que constrói laços ocorre através 
da conversação em rede (RECUERO, 2014) que, dentro da cibercultura, adquire especificidades, como o uso de emoticons, de imagens e gifs para expressar os sentimentos, a criação de grupos para discutir assuntos específicos e a criação de hashtags, capazes de linkar as conversações em torno de determinado objeto.

As interconexões entre milhares de atores geram movimentos de conversação que são capazes de trazer informações dos mais variados assuntos: tendências, sentimentos coletivos, interesses e intenções de grupos ativistas. A conversação em rede vai movimentar, também, a troca e a difusão de informações, pois ela possibilita que sejam captadas informações sobre os sentimentos de tribos, os interesses que as circundam e as suas intenções. Estas conversas públicas entre estes grupos que podem ser pensados como tribos são capazes de influenciarem a cultura a partir de suas interações. Esta conversação, que surge da interconexão entre milhares de atores, é uma característica social, não técnica, então, é importante destacar que o Facebook, por exemplo, é o espaço técnico que proporciona a emergência dessas redes de conversações.

Como coloca Recuero (2014, p. 35), "A apropriação técnica compreende o aprendizado do uso da ferramenta. A simbólica compreende a construção de sentido do uso dessa ferramenta (...).” Portanto, práticas sociais vão ganhar, através da linguagem, sentidos que podem ser percebidos através de movimentos desenvolvidos nas redes digitais. Por exemplo, "quando alguém publica uma mensagem e outro 'curte' o que foi dito, temos a formação de um par adjacente, já que o ator está tomando, ainda que de forma simbólica, parte na conversação e explicitando a sua aprovação" (RECUERO, 2014, p. 73). As performances desenvolvidas por atores sociais que buscam desenvolver sentidos vão, então, impactar diversos campos da sociedade. É neste cenário que eclodem os ciberacontecimentos (HENN, 2014).

\section{De Mônica Lewinski à capivara cachorro: a emergência dos ciberacontecimentos}

Os ciberacontecimentos são acontecimentos tramados em sites de redes sociais. Esta modalidade de acontecer iniciou-se nos anos 1990, tendo como marco, para Henn (2014), o escândalo envolvendo o ex-presidente dos Estados 
Unidos, Bill Clinton, e a então estagiária da Casa Branca, Mônica Lewinski. O gerente de uma loja de conveniência no edifício da rede de televisão norteamericana CBS deu forma inicial ao acontecimento, postando no seu blog, o The Druge Report, o conteúdo das conversas telefônicas gravadas pela amiga e denunciante de Lewinsky, Linda Tripp (HENN, 2013). Este ciberacontecimento já contém em si fortes questões relacionados ao público e ao privado que se desenvolvem nas redes através de signos e a dimensão acontecimental que assumem as celebridades. É na semiosfera (LOTMAN, 1996), que seria um mundo em nível sígnico, que o objeto (acontecimento) é transformando em signo e ganha interpretações por atores sociais e, em consequência, pelo jornalismo, criando, assim, mais signos, constituindo uma parte desse universo semiosférico. Ao movimento dos signos na semiosfera, dá-se o nome de semiose, que é vista, então, como os sentidos em torno de determinado ciberacontecimento, construídos através da ação dos signos. Como explica Henn (2014, p. 132):

É em Peirce (2002) que o conceito de semiose ganha estatura definitiva. Todo o signo se vincula a um objeto a partir de uma determinação lógica: o signo só existe em função de sua capacidade de representar, apontar ou sugerir um objeto, que, por conta disso, o determina. E o objeto não é necessariamente uma coisa: pode ser um sentimento, uma impressão, algo imaginado e não verbalmente expressável. Mas o signo somente se completa na medida em que gera um interpretante, outro signo que se vincula ao mesmo objeto. E o interpretante gera outros e outros, em um processo de potencialidade infinita (livre tradução dos autores) 4 .

É a partir do acontecimento que a semiose é impulsionada: ele surge como signo e gera infinitas possibilidades de desdobramento em torno do objeto que representa, por isso, entendemos que o acontecimento é portador de uma dimensão profundamente semiótica. Existem três dimensões que tornam

\footnotetext{
4 Es en Peirce (2002) que el concepto de semiosis gana la estatura definitiva. Todo el signo se vincula a un objeto a partir de una determinación lógica: el signo sólo existe em función de su capacidade de representar, apuntar o sugerir um objeto, que, por cuenta de eso, lo determina. Y el objeto no es necesariamente uma cosa; puede ser um sentimiento, uma impressión, algo imaginado y no verbalmente expresable. Pero el signo solamente se completa em la medida en que genera um interpretante, otro signo que se vincula al mismo objeto. Y el interpretante genera otros y otros, en um processo de potencialidad infinita.
} 
propícias a elaboração de um a ciberacontecimento: as transnarrativas e a hipermídia, construídas por diversos atores sociais; a reverberação, ou o espalhamento, que passa a construir as narrativas em torno de determinado acontecimento; e a eclosão de outras formas de acontecimento que se formam em cenários de conexões altamente sistêmicas (HENN, 2014). Assim, o caso em torno da capivara-cachorro possibilita pensar como um ciberacontecimento pode ser motorizado a partir de signos de entretenimento potencializados pela cibercultura, e que impulsionam a construção de sentidos através de atores sociais.

A partir das colocações vistas até agora, é possível entender a ruptura inaugurada pelo caso da capivara-cachorro. Através de uma publicação, aberta para que todas as pessoas que possuíssem um link pudessem visualizá-la no Facebook, o usuário Guilherme Down Dois Dtsa relatou que havia encontrado um cachorro em frente à sua casa, e que havia procurado na internet a raça dele, mas que não havia encontrado nenhuma informação. Ele disse também que o animal era manso e que já deu um banho nele, pois estava muito sujo e que se alguma pessoa fosse a dona do animal, que entrasse em contato, pois a raça deveria ser muito rara. Abaixo da publicação, seguiam duas fotos de uma capivara: uma coberta por lenços e outra sentada em um sofá. Assim, a partir das características da conversação em rede, as pessoas começaram a inaugurar sentidos em torno do caso e, em consequência, o espalharam em sites de redes sociais. A consequente visibilidade movimentou a semiosfera em torno do caso, impulsionando pautas jornalísticas e constituindo um ciberacontecimento.

\section{Da convergência ao espalhamento: como uma capivara-} cachorro se espalha em sites de redes sociais

No final da primeira década dos anos 2000, o livro Convergence Culture: where old and new media collide, do pesquisador Henry Jenkins (2006), trouxe uma série de postulações teóricas, a partir de exemplos práticos, que contribuíram, em um nível transnacional, para um maior entendimento do que estava ocorrendo com as mídias: um maior número de dispositivos tecnológicos e midiáticos contribuíam para que as pessoas desenvolvessem novas formas de 
sociabilidade, desencadeando transformações em vários aspectos culturais, econômicos e sociais. Das mobilizações coletivas, como os protestos que ocorreram no Brasil em 2013, aos casos de entretenimento, como a selfie da $86^{\mathrm{a}}$ cerimônia do Oscar, por exemplo, os atores sociais passaram a possuir um papel determinante para espalhar estes conteúdos em sites de redes sociais e, em consequência dos níveis de visibilidade alcançados, em blogs, veículos, portais, e coletivos por eles. Jenkins, em parceria com Joshua Green, especialista em estratégias digitais, e Sam Ford, consultor estratégico, vai adjetivar estes conteúdos com o termo espalhável5, na obra Spreadable Media (2013).

É comum, quando determinado conteúdo ganha alta visibilidade através do compartilhamento em sites de redes sociais, que ele seja referenciado como um viral. Por exemplo, quando um vídeo é compartilhado por muitas pessoas, ele é considerado um vídeo viral, tanto por agências de publicidade quanto socialmente. No entanto, Jenkins, Ford e Green (2013) desenvolvem uma crítica ao uso desta adjetivação a conteúdos compartilhados em demasia no ciberespaço. Para eles, o uso do termo viral em relação a determinados conteúdos faz com que se entenda o receptor não como um ser de sociabilidade, o que consequentemente subestima os públicos e coloca os produtores como únicos detentores do controle sobre as mensagens. Em contrapartida, os autores também vão criticar o conceito popular de meme, visto como algum conteúdo que desenvolve alta circulação. O conceito de Dawkins (1979), no entanto, coloca que o meme seria a menor unidade evolutiva de reprodução cultural. Assim, em determinado ambiente, um símbolo, uma música, uma peça de roupa, ganha características e se transforma devido aos aspectos sociais e culturais que vão sendo desenvolvidos a partir de suas reproduções.

Principalmente no Facebook, no Twitter e no Instagram, estes materiais que são propagados recebem o nome de memes, em alusão ao termo cunhado por Dawkins. Em contrapartida, o meme, dentro das propostas autorais

5 A versão original "Spreadable Media", foi traduzida para o português como "Cultura da Conexão". A tradução literal do termo "spreadable", que seria espalhável, foi traduzido como propagável. Por concordamos que a tradução literal conversa mais com as ideias metaforizadas e exemplificadas pelos autores, tomamos a liberdade de inserila no texto no lugar da tradução oficial. 
levantadas, está mais interno do que visível. Em totalidade, pode-se pensar, alinhando a ideia ao conceito de Lotman (1999) revisto por Henn (2014), que o gene está para biosfera como o meme está para a semiosfera. Assim, refletindo sobre a condição memética do uso dos sites de redes sociais no Brasil, é evidente a popularidade das chamadas correntes. Uma corrente consiste em, basicamente, uma pessoa ajudar a outra, o que já ocorria antes da cibercultura, por exemplo, quando os membros de uma comunidade eram convidados para uma corrente de oração para determinada causa. A publicação com a capivaracachorro traz características destas correntes, mas que acabam conversando com outros valores que contribuem para que um conteúdo tenha espalhabilidade.

Além de características mais técnicas, como a portabilidade e disponibilidade, os conteúdos, para desenvolverem espalhabilidade, devem tratar de temáticas que, através do estudo de Jenkins et al., (2013) são apresentados como mais espalháveis; são elas: fantasias e valores (práticas de fandoms, comunidade de fãs, em determinado contexto de sociabilidade), humor, paródias e referências, conteúdos inacabados, mistérios, controvérsias oportunas (gerar uma disputa de sentidos, posicionamentos, a partir de determinado conteúdo) e boatos. No que tange o caso da capivara-cachorro, em um primeiro nível há o mistério (o autor da publicação estava sendo sincero?), que se consome através do humor (sendo sincero ou não, os atores sociais julgam o caso cômico): primeiro, há um questionamento dos atores sociais em relação à veridicidade da possível confusão do autor e depois, mesmo que ele não esteja sendo sincero, os atores acham a situação cômica.

Tendo em vista as características e os sentidos inaugurados em torno da publicação da capivara-cachorro, detalhados no próximo item, fica evidente que o conteúdo é espalhado através dos sites de redes sociais por questões perceptíveis e que demonstram que os públicos são cientes daquilo que estão compartilhando, não dialogando com a terminologia, como já apontado pelos autores, de viralização. O que acontece é que, assim como Jenkins et al., (2013) nos explicam, os conteúdos, quando pensados a partir de estratégias, podem desenvolver espalhabilidade em determinados campos, como aconteceu com a 
capivara-cachorro. O autor da publicação, ciente do campo social em que estava inserido, e das especificidades culturais que o circundam, intencionalmente desenvolveu uma estratégia para que o conteúdo fosse compartilhado. Em entrevista ${ }^{6}$ para o portal de notícias R7, ele conta que estava com um amigo, sem fazer nada, e começaram a conversar sobre a viralização, entendida aqui como espalhamento, de publicações que pediam doações para pessoas doentes através de curtidas e compartilhamentos. Assim, apostou com o amigo que conseguiria confundir as pessoas, fazendo-as compartilhar uma bobagem qualquer. Em alguns dias, a publicação foi potencializada pelos sentidos que se instauraram em torno do caso a partir dos sites de redes sociais.

O próximo item apresenta as características e os sentidos inaugurados pelo caso, analisando o fenômeno sob o conceito de ciberacontecimento (Henn, 2014).

\section{Os sentidos inaugurados em torno da capivara-cachorro em sites de redes sociais}

A técnica de análise denominada como construção de sentidos em redes digitais (HENN, 2014) encontra-se em desenvolvimento. Na atual instância, ela possui inspiração nas metodologias de pesquisas qualitativas e quantitativas na internet (ver FRAGOSO et al., 2013). Nos casos analisados, parte-se da construção de uma amostra significativa, mas que não entre em redundância. Assim, rastreando os termos que levavam a determinado objeto através da busca nas redes digitais, os dados são coletados através de printscreen e armazenados em pastas para, posteriormente, passarem por uma análise de sentidos que busca entender os desdobramentos em torno de determinado objeto. Através desse caráter metodológico, que parte de uma pesquisa exploratória (FRAGOSO et al., 2013), percebemos, em pesquisa de campo no Twitter e no Facebook, durante os dias 14 e 15 de outubro de 2015, uma série de sentidos em torno do caso que serão especificados a seguir.

6 Disponível em: <http://noticias.r7.com/cidades/paranaense-diz-que-confusao-decapivara-com-cachorro-foi-brincadeira-mas-ja-recebeu-ate-proposta-29092015 > Acesso em: 16 fev. 2017. 
A publicação do dia 19 de setembro, no dia 15 de outubro de 2015, encontrava-se com mais de 3 mil compartilhamentos e 4 mil curtidas. Na área de comentários, predominam as marcações com outros atores sociais, seguidas de conversações que expressam humor, como o "kkkk", em um movimento que aponta dinamismo entre laços fortes e fracos (RECUERO, 2009). O processo evidencia o que apontam Jenkins et al., (2013, p. 234): para ser espalhado um conteúdo precisa ter facilidade de citação e compartilhamento. Muitos aplicativos e sites facilitam este processo, que acaba potencializando os significados em torno de determinado objeto. No caso da capivara-cachorro, os laços fracos levaram, através do espalhamento, o conteúdo até outros atores que agregaram visibilidade em torno da potência mobilizadora da capivaracachorro.

Em uma publicação7, também feita no Facebook, no dia 26 de setembro de 2015, Luciano Huck, apresentador de um programa na Rede Globo de Televisão, apropria-se da publicação da capivara-cachorro, oculta o nome do ator social/autor e potencializa os sentidos em torno do caso.

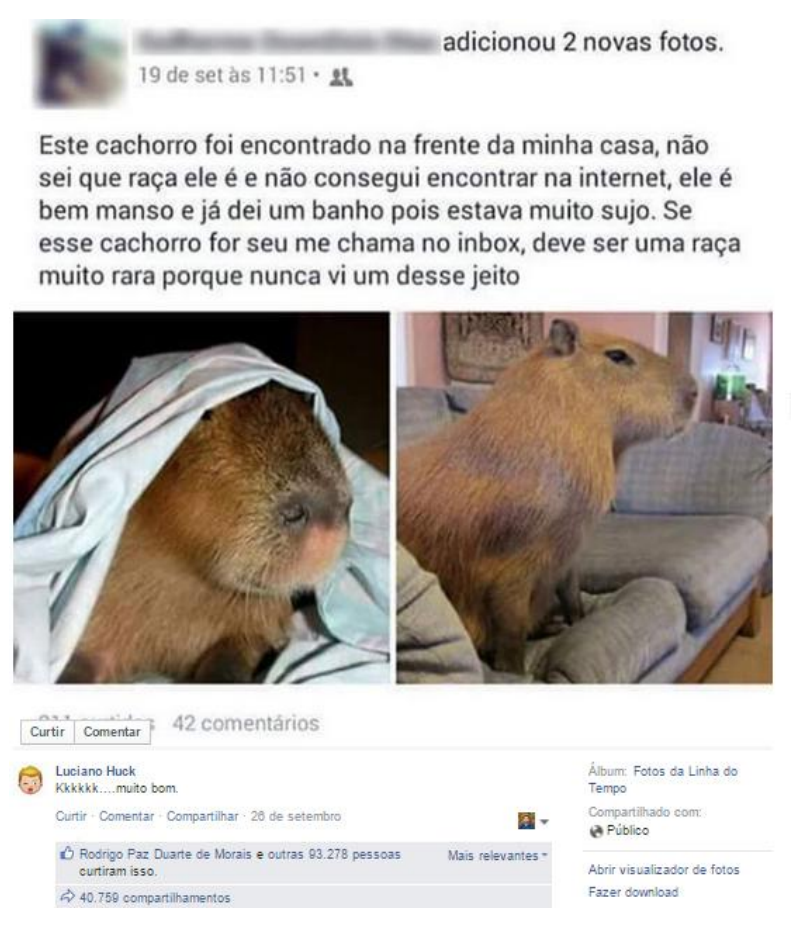

Figura 1: Luciano Huck e a capivara-cachorro Fonte: Perfil do Luciano Huck no Facebook

7 Disponível em: <https://www.facebook.com/LucianoHuck > Acesso em: 16 fev. 2017. 
A partir da publicação, fica evidente a dimensão acontecimental (SIMÕES, 2014) que algumas celebridades podem assumir, inaugurando campos problemáticos. Um campo problemático (QUÉRÉ, 2005) demonstra os enquadramentos $\mathrm{e}$ as transformações que vão ser dadas em torno de acontecimentos específicos. No caso em questão, ao modificar as estruturas da publicação original, por alguma razão que não fica clara (uma hipótese poderia ser o medo de algum processo oriundo do autor original, o que seria contraditório, tendo em vista que o autor divulgou o texto e as imagens em modo público; outra poderia ser a não disposição de Luciano Huck em ajudar o autor da publicação a desenvolver visibilidade e, em consequência, capital relacional. Nesse caso, a celebridade potencializa o espalhamento em torno do caso, ultrapassando, inclusive, os níveis de visibilidade da publicação original.

A afetação da celebridade em questão no acontecimento em torno do caso evidencia o papel que, na cibercultura, as celebridades desenvolvem com os ciberacontecimentos. Como coloca Simões (2014), os dons do corpo e do espírito que determinada celebridade possui constrói um poder que é capaz de afetar e sensibilizar a experiência dos sujeitos, que podem manifestar, ou não, o seu reconhecimento em relação às celebridades. A partir dessas processualidades entre as celebridades e seus públicos, entra em destaque o poder de afetação que pessoas célebres podem desenvolver, como no caso do compartilhamento de Luciano Huck, que, ao mesmo tempo em que contribui para a visibilidade em torno do caso, impulsiona a possibilidade da emergência de pautas jornalísticas.

Em consequência da visibilidade alcançada pelo caso, outro nó que entrou na rede, dessa vez sem ocultar o nome e a foto do ator social, ocultando apenas o seu sobrenome, foi a Prefeitura de Curitiba ${ }^{8}$. A página no Facebook, popular por desenvolver uma linguagem que traz elementos da cultura popular e da internet (OLIVEIRA; MENDES, 2015), acabou também potencializando os sentidos em torno do caso da capivara-cachorro, através de uma publicação ${ }^{9} \mathrm{em}$

${ }^{8}$ Disponível em: <https://www.facebook.com/PrefsCuritiba?fref=photo $>$. Acesso em: 16 fev. 2017.

9 Disponível em: <http://migre.me/rOLIP> Acesso em: 17 fev. 2017. 
que esclarece que o animal, em tom humorado, não era um cachorro, mas sim uma capivara, animal silvestre e livre para passear por Curitiba. A página pede também que as pessoas não levem as "capis" para as suas casas, e que o melhor que podem fazer com elas é uma selfie.

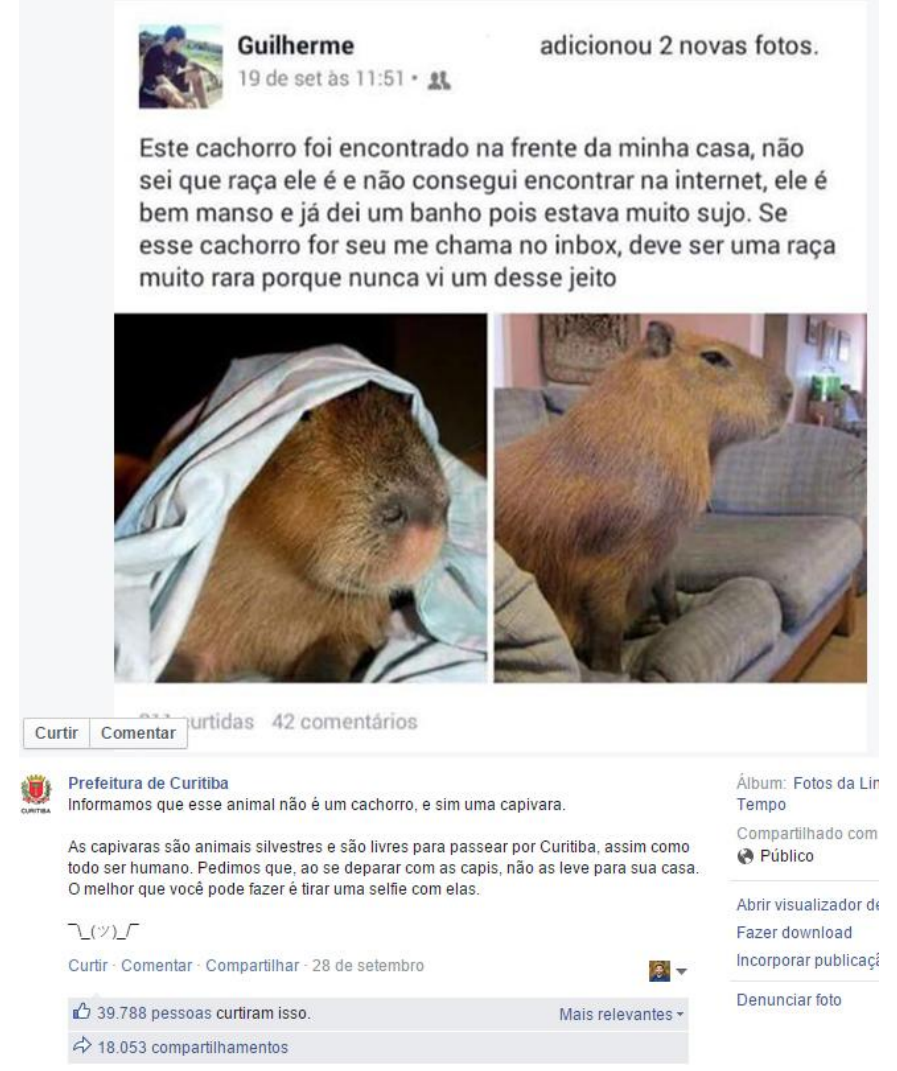

Figura 2: Capivara-cachorro em Curitiba Fonte: Página no Facebook da Prefeitura de Curitba

No Twitter, grande parte das publicações em torno dos termos capivaracachorro trazem o link de divulgação da publicação original, quase sempre precedido de risadas ou um choque, com fundo humorístico, em relação ao caso. Outras publicações que aparecem desenvolvem conversações que, por exemplo, pedem para que a história seja deixada como verídica, pois é muito "fofa", denunciam que as imagens estão presentes no Google Imagens(basta a busca por elas para perceber que a história é uma farsa), fazem piadas em relação ao olhar da capivara nas imagens, demonstram esgotamento em relação ao objeto capivara-cachorro e expõem que querem uma capivara. Alguns atores sociais buscavam esclarecer o caso a partir de uma imagem (Figura 3) que foi compartilhada e que trazia uma suposta conversa com o autor da publicação. 
Nela, Guilherme diz que nos primeiros dias ele achou que fosse mesmo um cachorro, mas depois que ele foi "zoado" demais, e acabou percebendo que se tratava de uma capivara. Respondendo à pergunta do ator que, aparentemente, o contatou, o autor disse que deu banho na capivara, que se chamaria Rodolfo e seria "bem mansinha”, e que dormiria nos pés da cama dele.

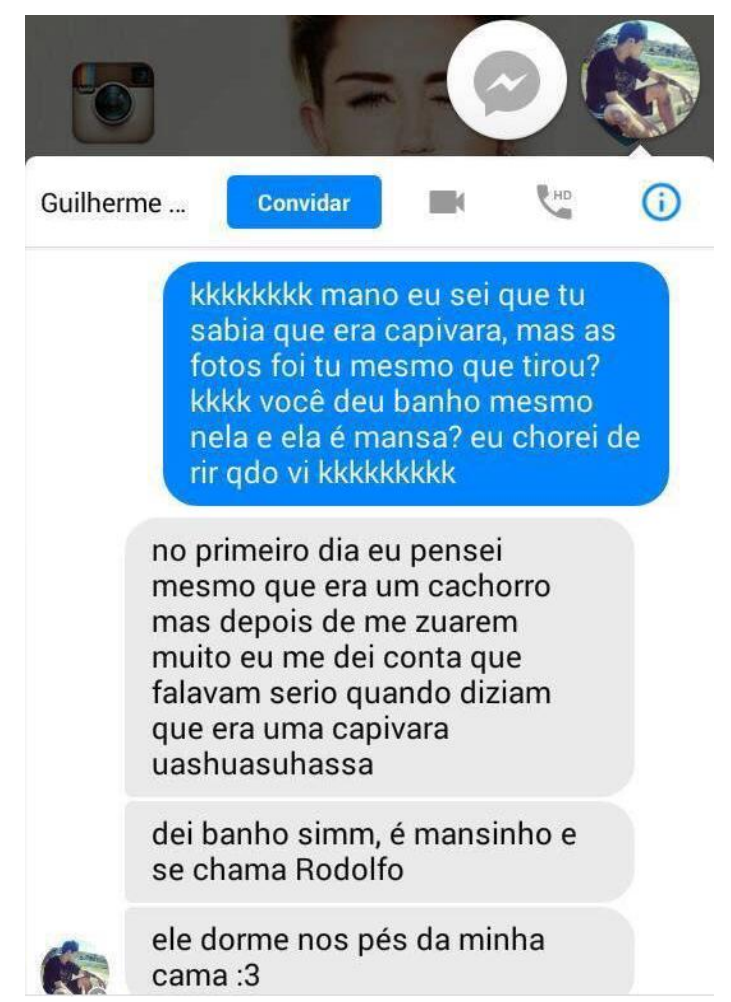

Figura 3: Prints da conversa no Twitter Fonte: Twitter

Outras publicações, no Twitter, desenvolviam conversações que buscavam esclarecer o caso, discutindo assuntos variados: de política a outros memes. Colocam que já existem outros assuntos do momento, demonstrando a fluidez e a velocidade dos assuntos na internet. Alguns falam de uma menina que cobraria para enviar nudes, outros publicavam que acreditar na capivaracachorro era possível, já que acreditaram na "grávida de Taubaté"10, uma mulher que inventou estar grávida de quadrigêmeos. Por fim, a conversação se estende a outros perfis, a partir da visibilidade do autor principal, buscando

\footnotetext{
${ }^{10}$ Disponível em: $<$ http://g1.globo.com/sp/vale-do-paraibaregiao/noticia/2014/12/falsa-gravida-de-taubate-se-livra-de-processo-na-justica-porestelionato.html>. Acesso em: 16 fev. 2017.
} 
encontrar um nome para o híbrido de capivara e cachorro, que como alguns colocam, seria um capinchorro.

A partir da matéria do $\mathrm{R} 7$, portal de notícias, o caso em torno da capivara-cachorro foi esclarecido, o que mobilizou mais pessoas a desenvolverem o espalhamento em torno da conclusão do caso, que, em sua maioria, a partir da conversação em rede, demonstrounessa construção de sentidos em redes digitais uma potência mobilizadora, que traz o humor como sentido predominante. Algumas horas antes da notícia, em sua página no Facebook, Guilherme continuou com as publicações que brincavam com a sua capivara-cachorro chamada Rodolfo, confirmando, possivelmente, a veracidade do printscreen da conversa que circulava no Twitter. A repercussão em torno da nova publicação ${ }^{11}$, na qual Guilherme dizia que havia levado, junto com mais uma pessoa, a capivara-cachorro para brincar no parque e que havia comprado um novo amiguinho para ela, um Chewbacca de pelúcia, não desenvolveu a mesma visibilidade que a anterior. A declaração do autor, em entrevista para o portal $R 7$, de que virais não ficam famosos por muito tempo e de que, com o tempo, pode aparecer outra publicação que vai chamar mais a atenção, sinaliza esta processualidade que chamamos, não em relação a virais, mas a conteúdos que se espalham pela web, de "morte do meme" - o que na verdade representa a sua mutação cultural a partir das dinâmicas digitais.

\section{Ciclo de vida do meme: a morte da capivara-cachorro}

O ciclo de vida em torno de determinado meme apresenta especificidades em relação a determinados casos, mas que, em sua maioria, apresentam fases que conversam com uma grande parte dos processos que se instauram em torno de um meme. Entendemos os seguintes ciclos como integrantes da visibilidade e consequente potência mobilizadora de uma unidade de reprodução cultural: o nascimento do meme, o seu espalhamento, o ciberacontecimento, o espalhamento potencializado, o surgimento de novos memes e, por fim, a morte metafórica do meme. Para dar continuidade, consideramos importante

${ }^{11}$ Disponível em:

<https://www.facebook.com/guiimatheus/posts/917453095004.381?pnref=story > Acesso em: 16 fev. 2017. 
desenvolvermos as discussões em torno do que seria especificamente esta unidade de reprodução cultural, em seu sentido empírico, popular e teórico.

Como já trouxemos para o texto, o meme é pensado, aqui, segundo Dawkins (1979) -junto a colocações de Henn (2014) e Recuero (2009) ${ }^{12}$ - que, a partir de conceitos biológicos, traz considerações sobre a cultura e a sociedade. Portanto, entendê-lo é menos complicado quando se conhece, resumidamente, o que são os genes. Os genes carregam as unidades básicas das informações genéticas, são eles que constroem o DNA humano. Em suma, para uma pessoa ter olhos claros, é necessário que ela herde essa informação genética através dos genes que seus pais transmitirão a ela. A vida, através da biosfera, então, só é possível através dos genes. O meme, assim como o gene, também é uma unidade básica de reprodução, só que em vez de genética, cultural. Quando pensamos na diferença entre as práticas culturais de uma região para outra, por exemplo, do Brasil e da Índia, elas se explicam através dos memes. Uma criança que nasce na Índia recebe, através dos seus pais, familiares, da sociedade, as informações culturais do seu país, o mesmo acontece com uma criança brasileira. O meme é o responsável pelo DNA cultural de um ser humano, é através deles que desenvolvemos as crenças e práticas que chegam até nós através dos mais variados signos. A vida, através da semiosfera, então, só é possível através dos memes, no sentido que eles são propulsores das ideias e, em consequência, da diversidade de signos.

Na cibercultura, o conceito de meme está ligado à ideia de Dawkins (1979). Quando pensamos na capivara-cachorro, por exemplo, o enunciado das palavras capivara e cachorro, compostas, já nos traz uma série de interpretações

${ }_{12}$ Destacamos a complexidade do conceito de meme proposto por Dawkins (1979). O que fazemos, aqui, é alinhar o pensamento de Henn (2014), pensando no ciberacontecimento, e de Jenkins, Ford e Green (2013), em relação ao espalhamento, para enxergar através da proposta do ciclo de vida do meme, como as relações em sites de redes sociais são altamente culturais e sociais e estão ligadas a aspectos mais complexas do que o conceito de viral, embora a percepção popular do meme também apareça como integrante às ideias desenvolvidas a partir da nossa pesquisa. A memética, estudo desses fenômenos relacionados a propagação de um meme, é vista como uma possibilidade de entender, alinhada aos outros conceitos trabalhados no artigo, em destaque o de ciberacontecimentos, como a imagem de uma capivaracachorro é espalhada na web. 
que estão instauradas em nós através da nossa cultura. Ao cachorro, associamos o animal doméstico, melhor amigo do ser humano, inimigo do gato, pulguento, brincalhão, etc.; à capivara, o animal selvagem, que lembra um porco peludo. Uma pessoa que acessa a página de Curitiba, por exemplo, famosa por fazer montagens utilizando capivaras, pode associar, também, a capivara a este conteúdo, refletindo, assim, os memes da cultura em que está inserida. Para melhor desenvolvermos a discussão, trazemos o gráfico abaixo:

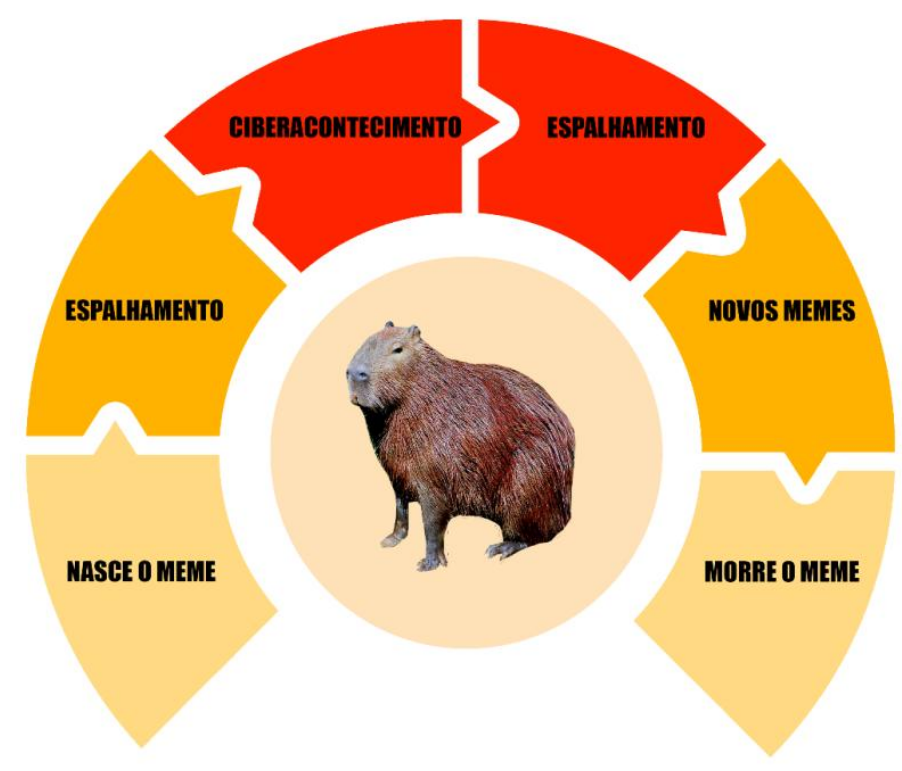

Figura 4: Ciclo de vida do meme capivara-cachorro Fonte: Elaborado pelos autores

O nascimento do meme em torno da capivara-cachorro ocorre, então, pela publicação do autor que dizia ter encontrado um cachorro de uma espécie rara. A partir dos signos disponíveis em seu "DNA cultural", o ator social desenvolveu um novo meme que mobilizou uma série de interpretações que geraram outros signos, através de um processo de semiose (HENN, 2014). As pessoas riam do fato de alguém confundir uma capivara com um cachorro devido às suas informações culturais em torno dos signos cachorro e capivara, que se apresentam de maneira bem diferentes. Assim, o meme começa a reprodução através de outros cérebros, em um processo de espalhamento.

Na fase do espalhamento (JENKINS et al., 2013), os signos inaugurados em torno do meme original vão gerar uma disputa de sentidos com outros 
memes, dentro de outros universos semiosféricos. Imaginemos o nosso universo transformado em símbolos, imagens, sons, palavras, um universo gigantesco de signos, dentro desse universo existem outros pequenos mundos, pequenas conexões, que são semiosferas inauguradas por determinados objetos. Estas semiosferas menores disputam sentidos para desenvolverem maior visibilidade dentro dessa semiosfera maior. Ao vencerem algumas disputas de sentidos, alguns memes, dentro da semiosfera, geram rupturas que, em consequência da maior visibilidade, representada pelas cores mais fortes na Figura 4, acabam gerando um campo problemático que impulsiona pautas jornalísticas. No caso da capivara-cachorro, o espalhamento e a potência mobilizadora impulsionada pelas semioses dos atores em sites de redes sociais em torno do meme fez com que eclodisse um ciberacontecimento em torno do caso.

$\mathrm{Na}$ fase do ciberacontecimento, o meme já passou por diversas reproduções, criando um rico acervo sígnico. É através desse nível que ele desenvolve mais visibilidade ainda, decorrente do campo problemático enquadrado e legitimado pelo jornalismo. Dentro de uma semiosfera com muitos memes, alguns casos desenvolvem visibilidade por mais tempo que outros. No caso da capivara-cachorro, o ciberacontecimento surge no nível mais alto de visibilidade, impulsionando mais compartilhamentos em torno do caso. A emergência do número de pautas jornalísticas é proporcional à visibilidade, mas, na maioria dos casos, o meme acaba chocando-se com outras semiosferas, chegandoà fase que compreendemos como a morte do meme.

A morte do meme é metafórica. Um meme nunca morre, ele apenas dissolve-se na semiosfera, composta por muitos outros memes e acaba ganhando diferentes formas - sofre mutações. Por exemplo, quando uma pessoa de olhos claros troca informações genéticas com uma pessoa de olhos escuros, a possibilidade de nascer um novo ser com olhos claros é reduzida, porque, geneticamente, olhos escuros são dominantes em relação a olhos claros. Com o passar dos anos, uma informação genética é capaz de ser descartada pela natureza, mas, ainda assim, o descarte surge de uma adaptação ao meio, sinalizando assim o caráter adaptativo dos genes. Em se tratando da capivaracachorro, após o nível máximo de visibilidade, vão surgir outros memes, como o 
"Senhora?"13, que vão acabar vencendo as disputas semiosféricas e desenvolvendo mais visibilidade que a capivara-cachorro, que acabou se mutacionando na semiosfera de informações culturais que integram o acervo do DNA cultural humano.

\section{Considerações finais}

Os conceitos de ciberacontecimento (HENN, 2014), espalhamento (Jenkins et al., 2013) e meme (DAWKINS, 1979), quando pensados alinhados à Semiótica (Henn, 2014), trazem considerações muito relevantes aos campos da comunicação. Os sentidos inaugurados em torno do caso da capivara-cachorro integram uma semiosfera que demonstra como a articulação destes campos de saberes pode sinalizar os aspectos culturais da contemporaneidade, ao mesmo tempo que traz considerações mercadológicas.

O mercado publicitário sempre almeja atingir o maior número possível de retorno de investimento em uma mídia. A visibilidade, em métricas, é uma das grandes formas de validar esse retorno. Por estas questões, o termo viral ganhou popularidade e passou a ser alvo de agências e clientes; no entanto, é impossível desenvolver um conteúdo viral, isto porque os públicos são seres de sociabilidade que, hoje mais do que nunca, possuem os dispositivos tecnológicos (JENKINS, 2006) para buscarem os assuntos dos seus interesses. O que se pode é, assim como o autor da publicação da capivara-cachorro, pensar em delineamentos que tornam um conteúdo dotado de espalhabilidade: a capacidade de ser espalhado pela web. Outra colocação que consideramos importante é que as formas de medir visibilidade são cada vez mais complexas. No caso da capivara-cachorro, por exemplo, em termos quantitativos, seria muito difícil mensurar a visibilidade em torno da publicação, isto porque o conteúdo ganha interpretações, que devido ao poder dos públicos, foge à norma imposta pelos produtores. O Facebook, por exemplo, prevê que alguém vá curtir, comentar ou compartilhar um conteúdo, mas, como demonstrado através

${ }^{13}$ Mais informações: <http://f5.folha.uol.com.br/voceviu/2015/10/1690301-meme-dasenhora-que-foge-de-entrevista-vira-jogo-para-smartphone.shtml >. Acesso em: 16 fev. 2017. 
da apropriação de Luciano Huck, atores sociais podem salvá-lo e editá-lo, e que uma republicação pode ter muito mais compartilhamentos que a original. Este movimento sinaliza problematizações para outros estudos, como a audiência das séries de televisão, que, como já sinalizaram Jenkins et al., (2013), foge também à lógica dos produtores.

O meme (DAWKINS, 1979) surge como unidade que dispara todos estes processos que se desdobram a partir de aspectos culturais. A partir da capivaracachorro, é inaugurada uma semiosfera que, a partir de signos, vai compor a narrativa do acontecimento específico. Fica evidente que os entendimentos destes processos trazem constatações que podem ser apropriadas para estratégias mercadológicas e para novos estudos que articulem o conceito de meme a outros aspectos culturais, fora, ou não, do campo dos ciberacontecimentos. A partir do estudo, percebe-se que uma capivara-cachorro sinaliza transformações muito mais importantes do que poderíamos imaginar.

\section{Referências}

DAWKINS, R. O gene egoísta. Belo Horizonte: Itatiaia, 1979.

HENN, R. O ciberacontecimento. In: VOGEL, D., MEDITSCH, E, e SILVA, G., Jornalismo e acontecimento: tramas conceituais. Florianópolis: Insular, 2013. P. 21-34.

El ciberacontecimiento: producción y semiosis. Barcelona: Editorial UOC, 2014.

JENKINS, H.Convergence Culture: Where Old and New Media Collide. NYU Pres,New York, 2006.

JENKINS, H.; FORD, S.; GREEN, J. 2013. Spreadable media: creating value and meaning in a networked culture. New York, New York University.

FRAGOSO, S; RECUERO, R.; AMARAL, A. Métodos de pesquisa para internet. Editora Sulina: Porto Alegre, 2011

LEMOS, André. Cibercultura: tecnologia e vida social na cultura contemporânea. $6^{\mathrm{a}}$ ed. Porto Alegre: Sulina, 2013.

LOTMAN, Yuri. La semiosfera. Catedra: Madri, 1996.

OLIVEIRA, Nathalia Bettoni; MENDES, Conrado Moreira. XX Congresso de Ciências da Comunicação na Região Sudeste - Intercom, 2015, Uberlândia. Facebook e Comunicação Organizacional: uma Análise do Modelo de Comunicação da Prefeitura de Curitiba . Disponível em: $<$ http://www.portalintercom.org.br/anais/sudeste2015/resumos/R480104-1.pdf >. Acesso em: 23 nov.2015. 
QUÉRÉ, L. Entre facto e sentido: a dualidade do acontecimento. In Trajectos - Revista de Comunicação, Cultura e Educação. Lisboa, nº 6, 2005, p. 59-76.

RECUERO, R. A conversação em rede: comunicação mediada pelo computador e redes sociais na internet. Porto Alegre: Sulina, 2012.

. Redes Sociais na Internet. 1. ed. Porto Alegre: Sulina, 2009.

SANTAELLA, L. Comunicação Ubíqua. Paulus: São Paulo, 2013.

SIMÕES, P. G. O poder de afetação das celebridades. In: FRANÇA, V. et al (Org.) Celebridades no Século XXI: transformações no estatuto da fama. Porto Alegre: Sulina, 2014. 